\title{
Comparing the Community Dependence on Natural Resources in Nyungwe National Park and The Contribution of Revenue Sharing Through Integrated Conservation and Development Projects
}

\author{
Ange IMANISHIMWE ${ }^{* 1}$, Theophile NIYONZIMA ${ }^{2}$, Donat NSABIMANA ${ }^{1}$ \\ 1. Department of Biology, School of Science, College of Science and Technology, University of Rwanda, P.O \\ Box 117 Huye, Rwanda \\ 2. Department of Geography, School of Architecture and Built Environment, College of Science and \\ Technology, P.O Box 3900, Kigali, Rwanda \\ *Corresponding Author Email: angeish07@gmail.com
}

\begin{abstract}
Rwanda Development Board (RDB) has recently established a tourism Revenue Sharing Scheme (RSS) to create a win-win approach in protected areas for effective biodiversity conservation and management. Through this scheme, around 1 billion Rwandan francs wereinvested to support around 152 Community Based Conservation Projects (CBCs), and integrated conservation and development projects (ICDPs). This paper assessed the contribution of CDCs projects around Nyungwe National Park (NNP) by evaluating their efficiency and effectiveness, and their socioeconomic impact to the local community development. Secondary data about the revenue sharing projects and the amount of money allocated to each project were collected from RDB office. Primary data were collected through the interview and focus group discussions. To verify the findings from RDB, interview and focus group discussion (FGD) were used. Interview was done with 500 households of local people around Nyungwe National Park and with community conservation wardens, while threats to NNP were verified by the consultation of reports from ranger based monitoring officers. The results showed that the value of resources collected by people from the park is higher than the revenue sharing support offered by RDB as $(31.3 \%)$ of respondents mentioned that exotic tree species were stolen and sold as poles where one pole was sold at around 6,800 Rwandan francs and 38.6\% of respondents proven that mining gave the much income. and consequently the revenue sharing scheme did not significantly reduce threats to biodiversity and its impact around NNP.A small percentage of people are happy because they were supported but a big number becomes unhappier and threaten the Park due to the gap in creating a win-win situation in biodiversity conservation. We recommend the revision of the whole revenue sharing scheme, taking into account the cost of livelihoods of community surrounding the park.
\end{abstract}

Key words: Efficiency, Effectiveness, Integrated Conservation, Development Projects, Revenue Sharing Scheme 


\section{Introduction}

Integrated conservation and development projects (ICDPs) are included in community based conservation projects (CBCs) and they are defined as approaches to the management and conservation of natural resources in areas of significant biodiversity value that aim to reconcile the biodiversity conservation and socio-economic development interests of multiple stakeholders and partners at local, regional, national, and international levels (Franks and Blomley, 2004). The term ICDP was firstly used in the Luangwa valley integrated conservation and development project jointly conducted by Food and Agriculture Organization (FAO) and the Government of Zambia in the mid-1960s (Child and Dalal-Clayton, 2004). Since then, the ICDPs have been widely used as the innovative idea and applied to many different types of conservation initiatives and projects around the World with governments and organizations whose primary mission was biodiversity conservation and community development around protected areas (Campbell and Vainio-Mattila, 2003).

ICDPs were conceived as one of the solutions to human wildlife conflicts and extreme poverty reduction around protected areas (Adams et al., 2004). The main purpose was that ICDPs may reduce threats to ecosystems and help in improving community livelihoods and reduce environmental degradation (Robinson and Redford, 2004). In addition, ICDPs were suggested to promote the financial stability of local communities through the use of funds invested in different development projects such as agriculture, and entrepreneurial activities (Adams et al., 2004), and they should be more likely successful when there is a proper understanding of the root causes of environmental degradation and when relevant national, regional, and international policies are understood by local people (Franks and Blomley, 2004).

Since its creation and investment in conservation studies, ICDPs failed to meet their objectives in different areas of the World. Adams et al. (2004) indicated that ICDPs were likely to fail because decision makers and implementers under considered the real socio-economic situation of the community around protected areas. These authors realized that issues associated with ICDPs failure were linked to the lack of integration of biodiversity conservation and poverty alleviation, lack of strong policies and law enforcement that help wildlife conservation and community development, leading to the competition for natural resources (Adams et al., 2004).

Wells et al. (2004) identified a number of factors associated with the failure of ICDPs, including over-optimistic goals settled by leaders in conservation activities, weak assumptions, unconvincing local participation in biodiversity conservation, corruption in revenue sharing funds distribution, lack of leadership in environmental conservation, targeting wrong threats, uncertain financial sustainability, low benefit generation to all local communities, and the focus on the needs of donors instead of the needs of the local people. McShane and Wells (2004) indicated that the cause of the failure was rooted in the top-down process, where beneficiaries were not consulted before the policy development and ICDPs projects implementation. To solve the problem, Sayer and Campbell (2004) suggested that successful ICDPs should focus on an understanding of existing environmental and social status as well as action research and the use of both local and external knowledge. They also suggested that the good governance of natural 
resources should motivate the payment of incentives to the local communities for sustainable management of biodiversity.

In Rwanda, Nyungwe forest reserve was promoted to the level of a national park in 2004. Back in the past, local communities used Nyungwe forest as a source of wild meat, timber, gold mining, honey-bee collection, land for cultivation and collection of other non-timber forest products such as medicinal plants and materials for making crafts (ORTPN, 2005). The upgrading of that forest reserve to the level of a national park increased the restrictions on access to natural resources, leading to substantial loss of income to the local communities as it was observed elsewhere (Namara, 2005). Instead, it promoted tourism with the aim of generating national income, and then compensates the income lost by the local people through revenue sharing programs (Beeton, 2006), and hence reinforce conservation of Nyungwe National Park (NNP). The revenue sharing money were used to finance the ICDPs and the implementation was mostly done by local government, local cooperatives, religious organizations, and local NonGovernmental Organizations (RDB, 2012).

The main objective of this study is to assess theContribution of community conservation projects on livelihood improvement of local people and sustainable biodiversity conservation in Nyungwe National Park. The study is specifically focusing on the following issues: (i) To examine the impactsof community conservation projects on livelihood improvement of local peoplethrough tourism revenue sharing programs in NNP. (ii) To examine contribution of revenue sharing in improvement of sustainable biodiversity conservation in NNP. (iii) To analyze the challenges for community conservation projects on livelihood improvement of local people and sustainable biodiversity conservation in NNP.

The study was set to answer the following research questions: Is there any impactsof community conservation projects on livelihood improvement of local peoplethrough tourism revenue sharing programs in NNP? Is there anycontribution of revenue sharing in improvement of sustainable biodiversity conservation in NNP? What are the possible challenges for community conservation projects on livelihood improvement of local people and sustainable biodiversity conservation in NNP? We hypothesized that tourism revenue sharing programs contributed effectively on socioeconomic development of the local communities around NNP.

\section{Methods}

\subsection{Study area}

Nyungwe National Park is located in the south-western part of Rwanda, in the Albertine rift region. It is tropical montane rain forest rich in biological diversity, some of them being endemic to the park or in the Albertine rift (Musabe, 2002). The park is located between $2^{\circ} 15^{\prime}$ and $2^{\circ} 55^{\prime}$ South and $29^{\circ} 00^{\prime}$ and $29^{\circ} 30^{\prime}$ East at an elevation gradient varying between 1,600 $\mathrm{m}$ and 2,950 m (Plumptre et al., 2002). This forest is continuous to Kibira National Park in Burundi (Weber, 1989; Dowsett, 1990; Vedder and Fashing, 2002).

This research was conducted in and around NNP, in Kagano Cell, Kitabi Sector of Nyamagabe District; Gahurizi Cell Kivu Sector of Nyaruguru District; Gisovu Cell, Twumba Sector of 
Karongi District; Kiyabo Cell, Bweyeye Sector of Rusizi District; and Buvungira Cell, Bushekeri Sector of Nyamasheke District (Figure 1). These locations were selected purposively, because there are many beneficiaries of NNP revenue sharing (RDB, 2012). First, five sectors surrounding the park were selected using a stratified random sampling technique in all five district which are adjacent to Nyungwe. This was done to capture variation in location, access to markets and income among villages. Secondly, in each of the five districts one sector that is contiguous to the forest was selected. Finally, total of 500 households were selected using a random sampling technique in selected five sector with the number of 100 households for each by considering the cells closer to NNP. For here one person in every household was interviewed and $56.2 \%$ of the respondents were between 21 and 40 years old, $14.2 \%$ were between 41 and 50 years old, while $29.6 \%$ were beyond 50 years old. For a total of 500 local people interviewed, around $38.6 \%$ were male, while around $61.4 \%$ were females. The reason behind of this high number of women interviewed due to the presence of women at home at daily time is high compared to the presence of men. Total 500 households were selected randomly in the cells located nearby the forest.

Secondary data about revenue sharing in NNP were collected from RDBoffice and the list of 152 projects supported through revenue sharing (RS), the amount of money spent on each project, the lists of threats that NNP is facing were collected with the main purpose to assess if there is a correlation between RS and decrease or increase in illegal activities in NNP. 


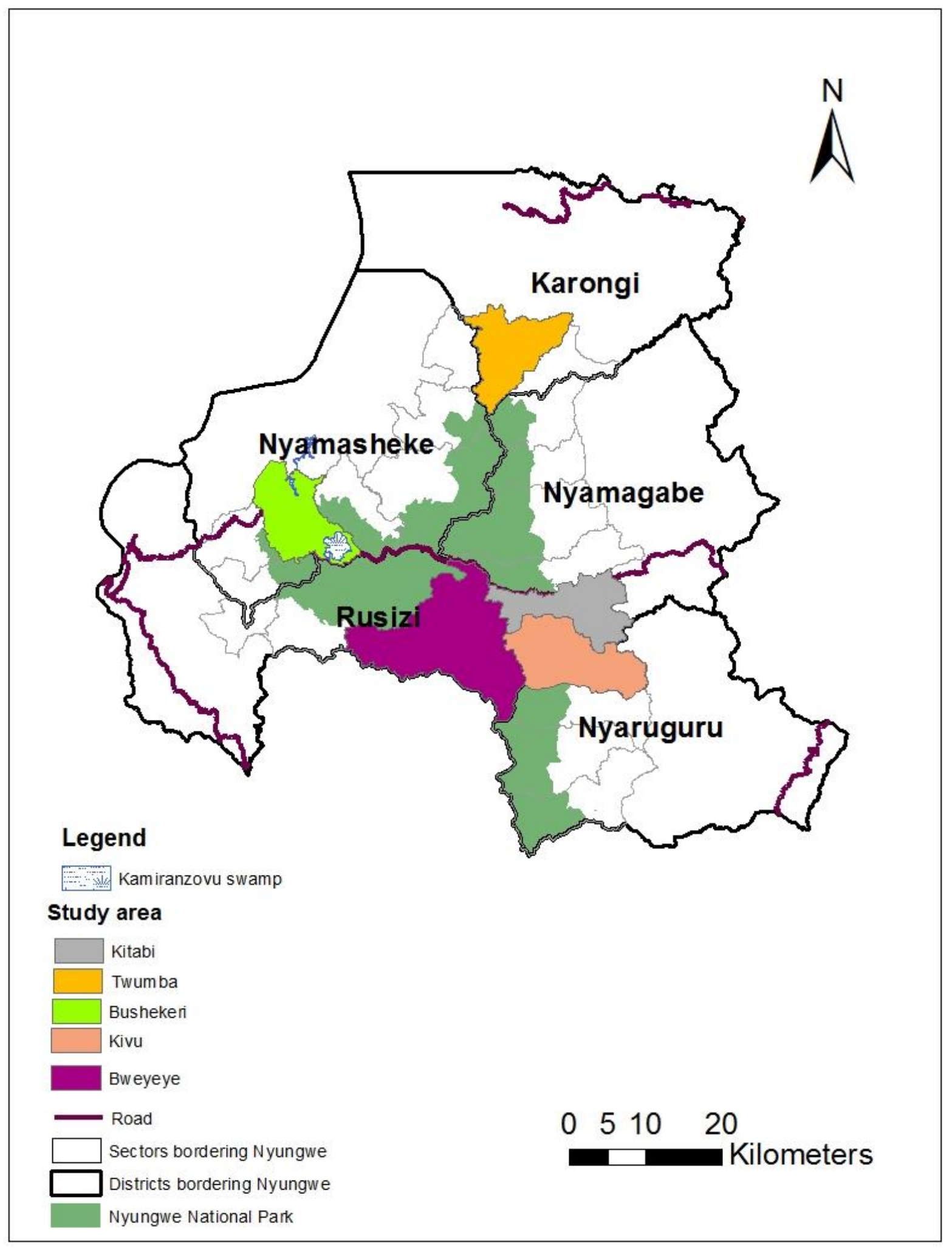

Fig. 1. Map of Nyungwe National Park with sectors that were selected for the study. 


\subsection{Data collection}

Between May and October, 2017, the questionnaire, which was developed originally in English, was translated into the local language (Kinyarwanda) and administered orally for interviewees outside of the population of study to test for the validity, clear understanding and clarity of questions. The questionnaire had three main sections including the respondent's background, questions about the role of biodiversity conservation and ecosystem services from NNP and the questions related to the use of tourism revenue sharing and its contribution to local community development.

In addition, section 2 and 3 were also discussed with local people through the focus group discussion (FGD). A total of 5 focus groups composed of 11 people selected themselves to represent others were organised, and there was a list of topics to discuss. Respectively, respondents were asked to report all natural resources they used to collect from the forest and now they are no longer allowed to collect from the forest. We also discussed about the income generated from these natural resources and the loss they face when they were stopped to use the forest natural resources. We were also interested to know the alternatives to replace the loss, and how they want to contribute to the conservation of the park. Finally, we discussed about the tourism revenue sharing, specifically how they obtained that funding, how they participate in the implementation of the project and the level of satisfaction by the contribution of RS on socioeconomic development.

To verify the findings from RDB office, interview and focus group discussion with local people, an interview was conducted with community conservation wardens.After, we visited the local area where these projects took place, in order to match the information from RDB, local communities and community conservation wardens. Reports done at the ranger based monitoring programs were also consulted in order to verify the level of threats on NNP.

\subsection{Data analysis}

Collected data were analyzed by the use of Microsoft excel for graphics and Management of Information System (MIST) software for maps. SPSS also was used for making statistical analysis likeCorrelationsbetween tourism revenue sharing and threats around NNP, and producing graphics and tables were used to compare our results while percentages were calculated to show the frequency of the situation and the perceptions of interviewed people. The Geographical Information System (GIS) was used to map illegal activities in the park referring to the ranger based monitoring (RBM) information. The households' dependence on the NNP was calculated as the ratio of annual income earned from forests to the total annual income earned from wealth and other sources such as agriculture, and off-farm employment in order to compare the revenue sharing support and the value of what people used to get from the forest and hence conclude if local people face the income loss from the resources that were collected from NNP as follows:

Household annual income $=\sum$ (Forest income + Agriculture income + Return to wealth + Wage income) (Campbell and Vainio-Mattila, 2003) 
To calculate the encounter rates, we summed up all observed illegal activities and divide them with the number of patrolled kilometers in a given time.

\section{Results}

\subsection{Correlation between threats reduction and tourism revenue sharing}

During our survey, we requested respondents to rank illegal activities in NNP, $92.6 \%$ mentioned snares as the first illegal activity in NNP, while $75.1 \%$ tree cutting scores on the second place. Yellow backed duiker, black fronted duiker, and bush pigs are the most poached wild animals as they were reported by $91.6 \%$. Participants in the focus group discussion reported that the black fronted duiker was sold at around 25,000 Rwandan francs, while the bush pig was sold at 31,000 Rwanda francs at the local market. They said that the yellow backed duiker was rarely sold at the local market because they are very few in NNP. They tend to extinct in this ecosystem. Trees collected in the forest were mainly used for timber and one timber was sold at between 1,200 and 3,000 Rwandan francs depending on the size and the tree species. The most tree species targeted by poachers are timber, bamboos and medical plants. Some of the respondents in the interview $(31.3 \%)$, mentioned that exotic tree species were stolen and sold as poles where one pole was sold at around 6,800 Rwandan francs.

Other activities that were realized in NNP but now are no longer allowed to do include mining reported by around $36.8 \%$ of the respondents, bee keeping reported by around $16.0 \%$, and collection of medicinal plants reported by around 3.1\% of the respondents. However, they didn't specify the amount of the income they generated from these activities.

Results indicated that some illegal activities from 2003 to 2013, the period after which Nyungwe forest was declared as national park and local people were stopped to collect natural resources in the forest. Snares and tree cutting come at the frontline of illegal activities mentioned by some local people (98.3\%). Data collected from rangers based monitoring indicated poaching, mining, tree cutting, bee keeping and forest fire to be the most occurring illegal activities (Figures 2, 3, and 4).

A computed correlation coefficient is calculated referring to the total number of signs of poaching against total number of kilometers walked by rangers. There is a positive correlation (0.49) between the number of kilometers patrolled (effort to search snares) and the number of poaching signs detection. But looking at the linkage of presence of illegal activities and revenue sharing, the calculations showed the negative correlation (-0.35). These figures show the encounter rates of illegal activities per kilometer and show us how illegal activities are spread in

the Park. With these figures we find high, medium, and low threats and we can easily know the sectors where there are a lot of or low trends of threats to the park. 

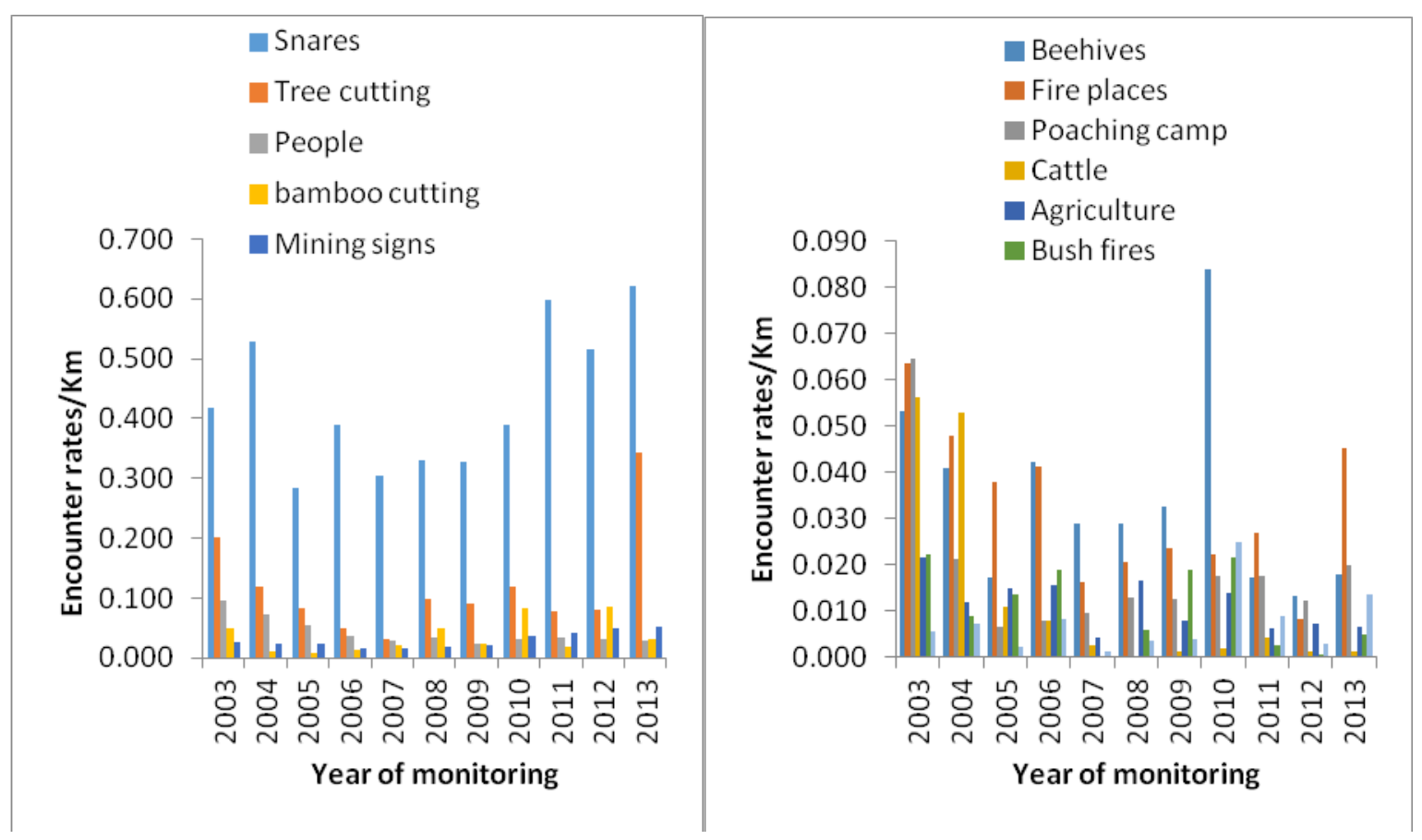

Fig. 2a. Frequency of High threats in NNP Fig. 2b. Frequency of Moderate threats in NNP 


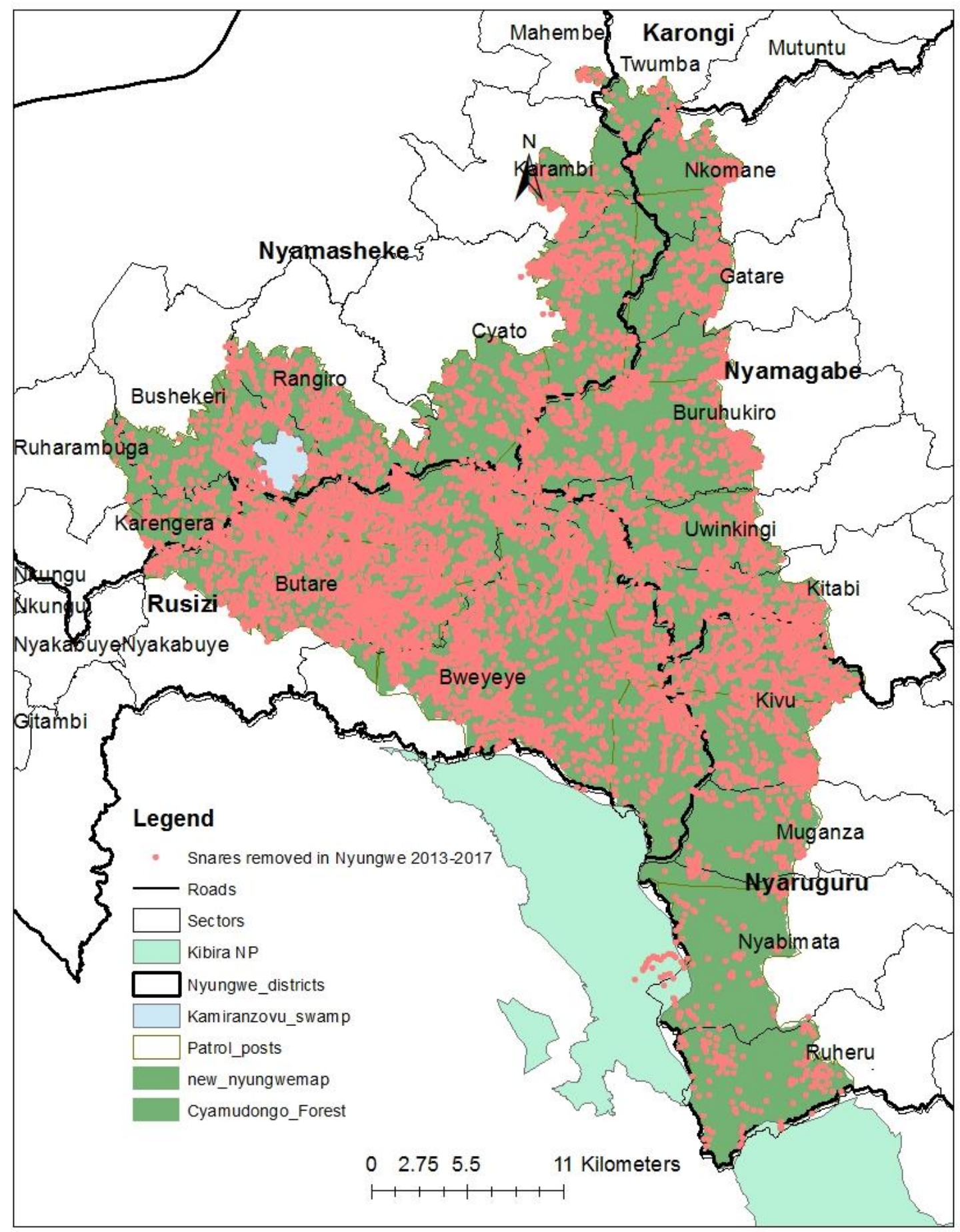

Fig. 3. Location of snares removed from Nyungwe between 2003 and 2017 


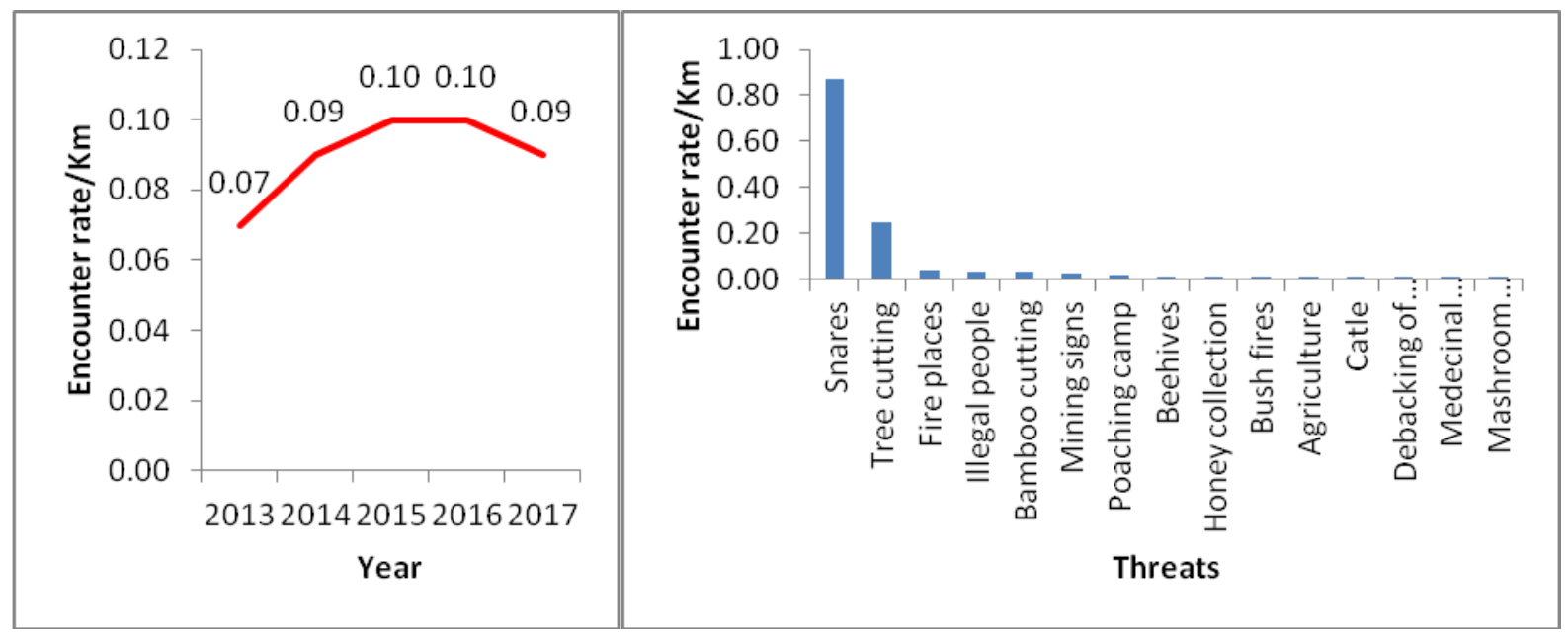

Fig. 4a. Mean average of encounter rate of

Fig. 4b. Threats encountered in NNP 2013-2017 threats in NNP 2013-2017

\subsection{Contribution of Revenue Sharing to improvement of community livelihoods}

Results indicated a total of 120 projects associated to the budget of 1,133,195,986 Rwf were financed through revenue sharing. These projects were implemented in Karongi, Nyaruguru, Nyamagabe, Rusizi and Nyamasheke. From 2013 to 2017, nineteen projects (12.5\%) were financed with RwF 100,651,872 in Karongi District, thirty-two projects (21.05\%) were sponsored with RwF 215,064,014 in Nyaruguru, while Nyamagabe got the funds for twenty-nine projects (19.07\%) with RwF 230,040,865, Nyamasheke received the funds of RwF 308,144,027 to support its 35 approved projects $(23.02 \%)$, and Rusizi has executed 37 projects (24.34\%) sponsored with RwF 279,295,208.

Funded projects were of different categories and included the money for park resources alternatives $(5.57 \%)$, (32\%) for income generating activities (32\%) and social infrastructures investment such as schools and hospitals was (62.4\%). While selecting the projects to be funded through the revenue sharing scheme we realized that there were steps adopted by Rwanda Development Board.

Data collected indicated that a revenue sharing of 5\% from tourism is used to develop communities around protected areas by supporting community projects like cooperatives related to conservation and infrastructure development, and the Government shifted from 5\% to $10 \%$ of which NNP gets $30 \%$ of the amount allocated from all three national parks (Nyungwe, Volcanoes and Akagera). The results showed that only $20.6 \%$ of interviewed people are benefiting from revenue sharing and it helps them to improve their livelihood.

Data from households' survey indicated that around $20.6 \%$ of the local people have accessed to the revenue sharing funds. Around $87.8 \%$ of the respondents indicated that the existing funds are not enough to finance any small-scale projects, so they use the funds only for home needs. All of 
them responded that the small revenue sharing affects the sustainability of the projects funded. For the challenges identified by local communities on revenue sharing scheme, $22 \%$ of the respondents identified limited funds for revenues sharing as a major problem, while $15 \%$ of the respondents reported the mismanagement and the lack of distributional consistent policy, and lack of fairness in distribution. Other $23.6 \%$ of the respondents suggested a need for increase of revenue sharing as a major solution, while $17.2 \%$ suggested the development of management strategies, government intervention and follow up, consistent revenue sharing distribution policy, and the use of co-management strategies.

For the improvement of their social economic development and compensation of the income lost from the natural resources they use to collect in NNP, around $26.8 \%$ of the local people interviewed suggested job opportunities, other 22.8\% want the support for their own and personal developmental projects, while $22.6 \%$ need the training on conservation and project development.

\subsection{Challenges faced by local administration and beneficiaries in management of revenue sharing}

$85.1 \%$ of local leaders at village and cell levels said that they are not aware of how projects are selected to be funded by Revenue Sharing and said they sometimes see people implementing projects in their administrative entities while they are not consulted. 51.1\% said that they have had conflicts with Revenue Sharing Grantees due to the lack of effective horizontal and vertical communication. $68.5 \%$ of the local leaders (at village and cell levels) who participated in this survey mentioned that Revenue Sharing projects are biased and corrupted. We were interested to share the questionnaires to the local leaders at Sector and District levels and 95\% of them are aware of Revenue Sharing but only $32.1 \%$ said that the selection is transparent. Asking RDB personnel in charge of community conservation, $85 \%$ said that the program is impactful at high level and only $15 \%$ said that the local government doesn't help in the follow up. $75.2 \%$ of beneficiaries mentioned that they are forced to give corruption to the local government and RDB staff working in community conservation projects.

This study revealed that there is no formal partnership agreement or memorandum of understanding (MoU) between the local government and RDB for effective communication and implementation of $\mathrm{CBCs}$ funded through the revenue sharing program. $87.3 \%$ of local leaders said that they are challenged on distributing the money to the Revenue Sharing Guarantees because most of the times they find money on sector account without knowing the projects that were chosen to be supported. This situation mentioned above results in getting complications during the visit of the Auditor General and most of the time the audit reports them to do embezzlement because of lack of clear Revenue Sharing administration from the District to the Grantee.

\section{Discussion}

Significant contribution in terms of money through revenue sharing was found in other studies even if the impact of the investment in CBCs is still minor (Kamuzinzi et al, 2015). While the government of Rwanda views tourism revenue sharing programs as a significant approach to rural development especially for the people around the national parks in terms of poverty alleviation, health promotion, economic empowerment, and education enhancement among other 
things findings of this study indicated that the local government and the community conservation wardens didn't put consistency in following up the impact of the projects supported through the revenue sharing scheme (Umuziranenge and Muhirwa, 2017) and this resulted in low appreciation of the contribution of revenue sharing to community livelihoods improvement (Imanishimwe et al., 2018).

This study indicated that a number of CBCs in which more than one billion Rwandan francs was invested in different developmental activities, but more than $80 \%$ of those projects are no longer there because of corruption, lack of project management skills, and plan for project sustainability. The same situation was observed in other countries as per the number of publications in community conservation sector (Kamuzinzi et al., 2015).

Even though our results showed that tourism revenues did not significantly contribute to the improvement of livelihoods around NNP (Kamuzinzi et al., 2015), other studies indicated how tourism is very powerful tool for economic development for the people around protected areas (Ian et al., 20017). From the social perspective, tourism promotes the respect and preservation of the communities' cultures (Global Education Center, 2005) and promotes human welfare (Simpson, 2008). For the environmental perspective, tourism has the ability to recover the degraded areas due to the reduction of over exploitation of natural resources (Ryan et al., 2009). This means that the issue is not tourism itself but the problem is how decision makers, managers, and practitioners implement the tourism revenue sharing policy.

The fact that there is no involvement of local communities in decision making, most of them were not even aware of this program and those who knew it expressed that it doesn't contribute much to their welfare. Our results showed that human wildlife conflicts, lack of education, and extreme poverty are the main issues and that the revenue sharing was not able to address them. This led to a number of threats to NNP as it was noted in the research of Kamuzinzi et al. (2015).

Some projects are no longer active (appendix 2) because the selection criteria were not strong enough and when the projects are supported, there is no consistent follow up due to the corruption factor and lack of accountability for some staff in charge.

Even though our studies showed that around one billion Rwandan francs was invested in CBCs around NNP, there was no significant ratio of income per household around NNP. Other studies showed that over the last ten years, tourism in Rwanda has recorded significant growth potential, with the industry's contribution to the country's Gross Domestic Product (GDP) increasing at a steady rate (Mwandosya, 2007). This scenario was observed because there was no transparency in projects identification and the corruption affects the effectiveness and efficiency of projects implementation. The beneficiaries did not get the real amount of approved funds and thus their objectives were not met (Kamuzinzi et al., 2015).

While the invested money in ICDPs around NNP should have contributed a lot to the job creation, there are no clear figures of created jobs and low numbers of employed people were observed. Apart from the employment opportunities, the tourism industry contributes significantly to the foreign exchange of many nations (Lee \& Chang, 2008). On the global scale, tourism generated revenue equivalent to US \$944 billion (UNWTO, 2013). It is not surprising that the tourism industry is considered a lead export sector that accounts for $30 \%$ of the total export service worldwide and nearly $45 \%$ in developing countries (UNWTO, 2010). For 
example, in one of the developing countries, in Rwanda, where this study is undertaken, tourism has been growing in terms of tourists' arrivals and revenue since 1998. Despite the number of tourists visiting NNP, most of the local people have never seen a dollar and there is no foreign exchange bureau around this park. This indicates that RSS didn't yet make local people financially smart.

The people adjacent to the park mentioned that what they get from illegal collection of forest resources is higher than the support they get from revenue sharing scheme and mentioned that the delay of compensating them when they face crop raiding by wild animals is one of the reasons that cause them to damage the forest. Regarding the knowledge of Nyungwe biodiversity, the respondents showed a good knowledge (Tables 1 and 2) but we realized that some people were not updated as they were mentioning animals absent in that park such as lions, buffaloes, and elephants.

Resources encroachment within protected areas especially in Nyungwe National Park indicates the danger of human pressures for resources as shown in the above results. Looking at the figures $2 \mathrm{a} \& \mathrm{~b}, 3$, and $4 \mathrm{a} \& \mathrm{~b}$ we got in this research; it is obvious that there is no significant decrease in illegal activity in the park. The number of illegal activities in the last 10 years was somehow low not because the poachers were not many at that time but because the RDB staff were few and during their patrols they could not cover a huge area to report all cases of illegal activities (RDB, 2015). In recent years, RDB increased the number of staff and the numbers of illegal activities increased because the staff was able to patrol different areas. Increase in equipment also resulted in finding a significant number of threats to biodiversity in NNP. Our results showed that there were the cooperatives of former poachers and beekeepers that were used to destroy the forest but some people are still involved in illegal activities in the Park (RDB, 2015).

\section{Conclusion and Recommendations}

Human activities in protected areas such as poaching, tree cutting, mining and bamboo cutting in Nyungwe National Park make biodiversity conservation more challenging. Poverty increase, lack of conservation ethics as well as misunderstanding of communities about biodiversity conservation are among the causes of people encroachment in the park. It is obvious that what people get from the forest is higher than what they get through Revenue Sharing Scheme. That is why illegal activities are still going on in Nyungwe National Park. The selection procedure of funded project has been corrupted as per local communities and the benefits are not equally shared. A small percentage of people are happy because they were supported but a big number becomes unhappier and threaten the Park due to the gap in creating a win-win situation in biodiversity conservation. The issue of human wildlife conflicts which is not solved professionally and on time reduced community engagement in NNP conservation. The Revenue sharing focused only on developmental projects didn't engage many people and it didn't provide conservation education. The scheme in the past 13 years was not capable to meet its goals and didn't show a measurable change in community livelihoods. With these scientific facts and figures, we recommend the Government of Rwanda to review the whole RS Scheme and build it on local community suggestions. The Special Guarantee Fund can be at Park level to solve issues on ground than being centralized. It is recommended that efforts in conservation education can be enhanced so the Park can celebrate safety in the future. We highly recommend that there can 
be a special program of RS Monitoring and Evaluation in Rwanda Development Board to ensure consistency in project identification and implementation. The impact evaluation is also advised to ensure the Sustainable Conservation of Nyungwe National Park. There is a need to assess the perceptions of the local people on the contribution of Revenue Sharing projects in their social welfare. An assessment on the effectiveness of revenue sharing to promote community livelihoods around the park is needed. We finally recommend that there can be a formal partnership agreement or MoU to be signed between RDB and local government in CBCs implementation and follow up consistently if all agreed articles are clearly implemented. Failing to the implementation we recommend that the District that was not honest and capable to deliver, can replaced by another district far from the protected areas and be given those funds for community development.

\section{References}

Adams, W. M., R. Aveling, D. Brockington, B. Dickson, J. Elliott, J. Mutton, D. Roe, B. Vira, and W. Wolmer. 2004. Biodiversity conservation and the eradication of poverty. Science 306:1146-1149.

Borrini-Feyerabend G., (1996). Collaborative Management of Protected Areas: Tailoring the A proach to the Context. Issues in Social policy, IUCN, Gland, Switzerland.

Campbell, B., J. A. Sayer, P. Frost, S. Vermeulen, M. Ruiz Pérez, A. Cunningham, and R. Prabhu. 2001. Assessing the performance of natural resource systems. Conservation Ecology 5 (2): 22. [Online] URL: http://www.consecol.org/vol5/iss2/art22/.

Campbell, L. M., and A. Vainio-Mattila. 2003. Participatory development and community-based conservation: opportunities missed for lessons learned? Human Ecology 31:417-436.

Carney, D. 1998. Sustainable rural livelihoods. What contribution can we make? Department for Internal Development, London, UK.

Child, B., and B. Dalal-Clayton. 2004. Transforming approaches to CBNRM: learning from the Luangwa experience in Zambia. Pages 256-289 in T. O. McShane and M. P. Wells, editors. Getting biodiversity projects to work: towards better conservation and development. Columbia University Press, New York, New York, USA.

de Botton, A. 2004. Status anxiety. Hamish Hamilton, London, UK.

Dowsett, R. J. (1990). Enquete Faunistique et Floristique dans la Forêt de Nyungwe, Rwanda. Tauraco Research Report, No. 3.

Fedderke, J. W., P. Perkins, and J. M. Luiz. 2006. Infrastructural investment in long-run economic growth: South Africa 1875-2001. World Development 34:1037-1059. 
Franks, P., and T. Blomley. 2004. Fitting ICD into a project framework: a CARE perspective. Pages 77-97 in T. O. McShane and M. P. Wells, editors. Getting biodiversity projects to work: towards better conservation and development. Columbia University Press, New York, New York, USA.

Gartlan, S. 2004. Land tenure and state property: a comparison of the Korup and Kilum ICDPs in Cameroun. Pages 208-231 in T. O. McShane and M. P. Wells, editors. Getting biodiversity projects to work: towards better conservation and development. Columbia University Press, New York, New York, USA.

Gunderson, L., and C. S. Holling. 2002. Panarchy: understanding transformations in human and natural systems. Island Press, Washington, D.C., USA.

Hellquist, A. 2004. Are divergent preferences between benefactors and beneficiaries an obstacle to community-based conservation? A case study of the Palas Valley, northern Pakistan. Dissertation. Lund University, Lund, Sweden.

Ian E. Munanura, Kenneth F. Backman, Edwin Sabuhoro, Robert B. Powell \& Jeffrey C. Hallo (2017): The perceived forms and drivers of forest dependence at Volcanoes National Park, Rwanda, Environmental Sociology, DOI: 10.1080/23251042.2017.1414661

Imanishimwe A, Nsengimana V, Nsengumuremyi C (2018) Contribution of Ecotourism to the Conservation of Nyungwe National Park in Rwanda. J Tourism Hospit 7: 348. doi: 10.4172/2167-0269.1000348

KamuzinziPhiona K., Shukla J., Ndabaga E., 2015. The effectiveness of Rwanda Development Board Tourism Revenue Sharing Program Towards local community socio-economic development: A case study of Nyungwe National Park. European Journal of Hospitality and TourismResearch 3(2): 47-63.

Kanyamibwa, S. (1992). La biodiversité des forêts de montagne du Rwanda et les problèmes de leur conservation. ConférenceMinagri, JournéeNationale de l'Arbre.

Kiss, A. 2004a. Is community-based ecotourism a good use of biodiversity conservation funds? Trends in Ecology and Evolution 19:232-237.

Kiss, A. 2004b. Making biodiversity conservation a land-use priority. Pages 98-123 in T. O. McShane and M. P. Wells, editors. Getting biodiversity projects to work: towards better conservation and development. Columbia University Press, New York, New York, USA.

Knotts, H. G. 2006. Sticks, bricks, and social capital: the challenge of community development corporations in the American deep south. Community Development Journal 41:37-49.

Kremen, C., J. O. Niles, M. G. Dalton, G. C. Daily, P. R. Ehrlich, J. P. Fay, D. Grewal, and R. P. Guillery. 2000. Economic incentives for rainforest conservation across scales. Science 288:1828-1832. 
Lam, W. F. 1996. Improving the performance of small-scale irrigation systems: the effects of technological investments and governance structure on irrigation performance in Nepal. World Development 24:1301-1315.

Leach, M., R. Mearns, and I. Scoones. 1999. Environmental entitlements: Dynamics and institutions in community-based natural resource management. World Dev. 27(2):225-247.

Levang, P., E. Dounias, and S. Sitorus. 2003. Out of the forest, out of poverty? Pages. 1-35 in Proceedings of the International Conference on Rural Livelihoods, Forests and Biodiversity (Bonn, 2003). Center for International Forestry Research, Jakarta, Indonesia.

McShane, T. O., and M. P. Wells. 2004. Integrated conservation and development? Pages 3-9 in T. O. McShane and M. P. Wells, editors. Getting biodiversity projects to work: towards better conservation and development. Columbia University Press, New York, New York, USA.

McShane, T. O., and S. A. Newby. 2004. Expecting the unattainable: the assumptions behind ICDPs. Pages 49-76 in T. O. McShane and M. P. Wells, editors. Getting biodiversity projects to work: towards better conservation and development. Columbia University Press, New York, New York, USA.

Musabe, T. (2002). Use of Non Timber Forest Products (NTFPs) and it Ecological Impact on the Conservation of Nyungwe Forest Reserve in Rwanda. A Thesis Submitted in Partial Fulfilment for the Award of the Degree of Master of Environmental Studies (Science), Kenyatta University.

ORTPN (2005), General Management Plan of Volcanoes National Park. Musanze, Rwanda Government of Rwanda.

Ostrom, E. 1990. Governing the commons: the evolution of institutions for collective action. Cambridge University Press, Cambridge, UK.

Plumptre, A., Masozera, M., Fashing, P. J., McNeilage, A., Ewango, C., Kaplin, B.A. \&Liengola, I. (2002). Biodiversity surveys of the Nyungwe Forest Reserve in S. W. Rwanda, WCS Working Paper, 19.

Plumptre, A.J., 2003. Lessons learned from on the-ground conservation in Rwanda and the Democratic Republic of Congo. In: S.V. Price, ed. 2003. War and Tropical Forests: Conservation in areas of armed conflict. New York: The Haworth Press Inc. 71-91.

Robinson, J. G., and K. H. Redford. 2004. Jack of all trades, master of none: inherent contradictions among ICD approaches. Pages 10-34 in T. O. McShane and M. P. Wells, editors. Getting biodiversity projects to work: towards better conservation and development. Columbia University Press, New York, New York, USA.

Rogers, P. J. 2005. Africa, Africanists, and wildlife conservation. African Studies Review48:143153. 
Salafsky, N., G. Cauley, B. Balachander, J. Cordes, C. Parkes, C. Margoulis., S. Bhatt, C. Encarnacion, D. Russell, and R. Margoulis. 2001. A systematic test of an enterprise strategy for community-based biodiversity conservation. Conservation Biology15:15851595.

Salafsky, N., R. Margoulis, K. H. Redford, and J. G. Robinson. 2002. Improving the practice of conservation: a conceptual framework and research agenda for conservation science. Conservation Biology16:1469-1479.

Sayer, J., and B. Campbell. 2004. The science of sustainable development. Cambridge University Press, Cambridge, UK.

Scott, J. C. 1998. Seeing like a state: how certain schemes to improve the human condition have failed. Yale University Press, New Haven, Connecticut, USA.

Sharma, S., H. C. Rikhari, and L. S. Palni. 1999. Conservation of natural resources through religion: a case study from central Himalaya. Society and Natural Resources12:599-612.

Sivaraksa, S. 1989. Development and environment in south-east Asia. Zulak24:429-436.

Smith, R. J., and M. J. Walpole. 2005. Should conservationists pay more attention to corruption? Oryx 39:251-256.

Umuziranenge G., Muhirwa Fabien (2017). Ecotourism as Potential Conservation Incentive and its Impact on Community Development around Nyungwe National Park (NNP): Rwanda. Imperial Journal of Interdisciplinary Research (IJIR) Vol-3, Issue-10, 2017 ISSN: 24541362, http://www.onlinejournal.in

Weber, W., 1987. Ruhengeri and its resources. An Environmental Profile of the Ruhengeri Prefecture, Rwanda.

Wells, M. P., T. O. McShane, H. T. Dublin, S. O’Connor, and K. H. Redford. 2004. The future of integrated conservation projects: building on what works. Pages 397-422 in T. O. McShane and M. P. Wells, editors. Getting biodiversity projects to work: towards better conservation and development. Columbia University Press, New York, New York, USA.

Wunder, S. 2001. The economics of deforestation: the example of Ecuador. Palgrave Macmillan, Basingstoke, UK.

Wunder, S. 2005. Payments for environmental services: some nuts and bolts. CIFOR, Bogor, Indonesia.

Zerner, C., ed. (2000). People, plants, and justice: The politics of nature conservation. New York: Columbia University Press. 